Research Square

\title{
Development Of An Excel-Based Cost Effectiveness Analysis Tool For Ascertaining Value For Money In Implementation Of Hiv And Other Health Interventions At Bomu Hospital, Kenya
}

NANCY MUCOGO NJERU ( $\square$ NNJERUM@GMAIL.COM )

Kenya Ministry of Health https://orcid.org/0000-0002-3746-5915

Elizabeth Owiti, PhD

University of Nairobi

Aabid Ahmed, PhD

Bomu Hospital

\section{Research}

Keywords: Economic evaluation, Costing, Resources, Treatment outcomes

Posted Date: March 28th, 2020

DOI: https://doi.org/10.21203/rs.3.rs-18480/v1

License: @ (i) This work is licensed under a Creative Commons Attribution 4.0 International License. Read Full License 


\section{Abstract}

An Organization Capacity Assessment done in Bomu hospital in April 2015 with an aim to strengthen the local institution's capacity for sustainable fight against HIV Aids pandemic led to the development of this excel-based cost effectiveness analysis tool. Objective: The specific objectives were to develop a cost-effectiveness analysis excel tool complete with instruction manual for use in costing, determining prices of services and carrying out economic evaluations.

Method: A technical working team (TWG) comprising of senior management of the hospital and the University of Nairobi Fellow was formed. The TWG identified program where cost indicators would be derived, developed cost indicators collection tools, collected costing data and build necessary consensus and assumptions. The data was used to design the tool complete with working instructions.

Results: The tool comprises of processes, instructions, excel data entry provisions and inbuilt formulae in excel sheets. The unique tool features include; simple to use instructions, systematic listing of cost elements with a drop down option to allow selection as required, allows additional cost elements to be added thus increasing scope of use. The tool also separates costs and sub-costs in a manner that allows cost drivers to be known precisely as well as avoid double costing among others.

Conclusion: The tool is transferable to other facilities and can be replicated in all hospitals within the country, in private, public and non - governmental organizations. Its regular review, improvements and utilization will be important for the health sector to fully benefit from its use. It will be necessary to sensitize health facilities to address information gaps and also ensure that data is available in form and detail necessary for costing purposes.

Key words: Economic evaluation, Costing, Resources, Treatment outcomes

\section{Introduction And Background}

1.0 Introduction

The organizational capacity assessment (OCA) carried out in Bomu hospital in April 2015 identified various gaps under health economics requiring strengthening. The OCA process utilised a participatory approach and established that costing of services to inform pricing of services as well as health economic evaluations were not conducted on a regular basis at the hospital. This project will facilitate the process by developing a cost effectiveness analysis excel based tool that will be utilized by the hospital on a regular basis.

\subsection{Background}

Escalating expenditures on health and limited health care budgets have highlighted the need to use resources effectively and efficiently and the desire has arisen to implement evidence-based policy decisions. Health economics and economic evaluation have thus acquired greater prominence among decision makers, who need to know which interventions represent 'value for money', (WHO 2008).

It has been observed that a lot of spending in health is as a result of advances in medicine, improved diagnostic tools, advances in surgical interventions, improved therapies and more effective pharmaceuticals (James W. $\mathrm{H}, 2012$ ). In addition and mostly in developing countries, the fight against infectious diseases such as HIV, TB and Malaria (in addition to maternal and child health) have also led to high healthcare investments and expenditures, e.g. HIV alone has placed tremendous demands on the health system and the economy. In Kenya, the total health expenditure on HIV/AIDS (THEHIV) was KSh 43.7 billion (US\$532.1 million) in 2012/13, up from KSh 40.3 billion (US\$511.9 million) in 2009/10 accounting for 19 percent of THE in 2012/13and $1.3 \%$ of the overall Kenya GDP in 2012/13 (NHA, 2012-2013).

The current 90-90-90 United Nations strategy on HIV/AIDs to get HIV epidemic under control and based on the principle of universal testing and treating requires more financial investments from both donors and respective governments. In addition, declining donor funding for the health sector in a county that relies heavily on donor funding requires that conscious efforts are made to utilize every available resource effectively.

Health economics and application of economic evaluations for health interventions can thus be made an integral component of the routine practices in our health institutions to address the need for maximizing output for every available resource. This is based on the fact that resources are scarce and at no one time shall we have all that we require to meet all our public health needs. It attempts to apply the theories, concepts and techniques of economics to the institutions, actors and activities that affect health, (Ann \& Kenneth, 1993).

Cost effectiveness analysis is one of the methods that can be utilized to undertake economic evaluations. The method specifically involves assessing the gains (effectiveness) and resource input requirements (costs) of alternative ways of achieving a specified objective usually expressed in terms of cost per unit of effectiveness for each alternative, (Andrew C. \& David P. 1994). It involves showing how costs and effectiveness could be combined to derive measure of efficiency. Efficiency is related to cost-effectiveness. It is a term used to define the relationship between outputs and inputs, (Lorna \& Virginia 2011). There is both technical efficiency (carrying out agreed activities using the least possible resources) and allocative efficiency (directing resources to their most productive use) (Sophie W. et al 2000). The method will be utilized as it is relatively easy and simple to conduct.

\subsection{Bomu}

Bomu Hospital is a 'not for profit 'organization established is the late 1970s as a clinic by a group of philanthropists to provide accessible, affordable, and quality healthcare services in Mombasa. The facility was among the first in the country to initiate Anti-Retroviral Therapy (ART) services and currently, through 
a very strong HIV component provides comprehensive integrated HIV services to over 21,000 active adult and paediatric clients in Mombasa, Kilifi and Kwale Counties making it the largest HIV program in Coast.

Bomu Hospital: Changamwe, Mombasa County

The HIV component operates the following services: HIV Testing and Counseling, Care and Treatment, Prevention of Mother to Child Transmission of HIV, HIV Exposed Infant program, Youth Friendly Clinic, Orphan and Vulnerable Children, Nutrition, and screening and treatment of TB. These services are supported by a strong community program operating with over 100 community health workers. The program's success is evident with a mother - to - child HIV transmission rate of less than $2 \% .95 \%$ of adults and $100 \%$ of the paediatric clients receive life - saving antiretroviral medicines and treatment of opportunistic infections at no cost. Supportive services such as laboratory monitoring and Gene Xpert for TB is also provided free of charge to the patient. Currently, the facility is a fully fledged level 4 Hospital that has also achieved ISO 9001:2008 certification including the accreditation of its medical laboratory to ISO 15189:2012.

1.3 Problem statement

Bomu's growth has been solid and transparent with good governance which has resulted to sustained donor funding (BMC-SP 2010-2015). The hospital has various supporting partners who have supported its tremendous growth. Despite this, the OCA reported conducted in Bomu hospital identified various gaps in health economics where economic evaluations were not conducted regularly. This is mainly due to lack of expertize and skills especially with the involvement of cost measurement where prior accurate and reliable data to inform economic evaluation hinders the process. There is also no substantive staff in charge of health economics. In addition, and due to lack of evidence based economic research, the hospital relies on external market forces in the costing of services. This was also done through comparison with other hospitals for both quality and costs.

Though Bomu has been able to mobilize resources, resources are not normally adequate given the competing health needs or institutional needs. Therefore, Bomu Hospital must prioritize its HIV activities and to do this successfully, they need to understand the costs and the health benefits of various interventions.

Secondly, there are varying HIV interventions within the HIV Programme geared towards prevention of infections and treatment of those that are already HIV positive. Bomu needs to estimate the costs of various interventions and also track the effectiveness (benefits) of each intervention with the view of implementing the interventions that will give the greatest benefit at a reasonable cost.

Thirdly, HIV interventions are life- long in nature; Bomu Hospital needs financial sustainability in order to ensure the long-term provision of HIV services. One way of increasing financial sustainability is through increasing savings by employing cost saving initiatives. Cost effectiveness analysis findings would enable Bomu to make the right decisions.

Fourthly, in the need for value for money assessment, the hospital should be able to assess if they are using the resources both monetary and non-monetary (human resources, infrastructure, commodities etc.) in the most efficient way possible and getting the greatest health benefit achievable. Are there areas in which the hospital can get the same output at a lower cost or more output at the same cost or better output at a higher cost? These are questions that the management struggles with every day and yet cost effectiveness analysis can provide some of the answers.

For purposes of such informed decision making it is important then for the hospital to strengthen health economics in order support health care financing and planning. A cost effectiveness analysis tool will thus be developed to facilitate conduction of cost evaluations at the hospital. The tool, which will address aspects of costing for services as well as evaluation for effectiveness of health interventions will be the first of its kind at the hospital to inform health care financing, budgeting and costing decisions.

\subsection{PROJECT OBJECTIVES}

\subsubsection{Goal}

The main goal of this project is to develop of a cost-effectiveness analysis tool for ascertaining value for money in implementation of HIV programs and interventions at Bomu Hospital. This will contribute towards maximizing human welfare and utility by employing scarce health resources cost-effectively.

\subsubsection{Purpose}

The purpose is to facilitate regular conduction of economic evaluations on HIV programs and health interventions at the hospital through development of a cost-effectiveness analysis tool.

\subsubsection{Specific objectives}

1. To develop a cost-effectiveness analysis excel tool

2. To develop a cost-effectiveness analysis manual/instructions

3. To pre-test the tool

4. To train on the use of the tool and disseminate lessons learnt

\subsection{JUSTIFICATION/ SIGNIFICANCE}

Bomu has many supporting partners and the call for evidence of interventions and value for money is a reality. Prioritization of services in the light of scarce resources and the competing needs is thus an important goal in an institution seeking to address the dire lack of accessible and affordable health care service for all without excluding the poor. The application of economic evaluation will therefore help to determine how resources can give the greatest benefit as well 
as help the hospital in promoting efficiency and equity during service delivery. There is also an increasing demand for going beyond accountability and transparency with the need for further evaluations of economic feasibility of health interventions even before they are implemented.

Few health institutions are able to perform economic evaluations for their health interventions. The major setback lies in lack of expertize and skills which is also the case in Bomu hospital. The project therefore aims to develop a tool that the institution will utilize regularly to carry out cost-effectiveness analysis on its HIV programs and health interventions. This will be a simple tool that is easy to use. Secondly, the process will build capacity of the hospital staff to appreciate the need to continuous economic evaluation at the hospital and use of the tool. Thirdly, the informed decision making role of economic evaluation in health care will be clearly captured.

\subsection{Project Implementation Methods And Management Plan}

\subsection{Methodology}

The project was implemented through a participatory approach through establishment of a technical working team (TWG) to participate in the project implementation. The key institutional issues for consideration included senior management involvement and commitment as well as the co-ordination of activities, oversight and transparency. Secondly provision of incentives, training and supervision of staff involved was done for motivation and to maintain morale.

\subsection{Roles and responsibilities}

Table 1

Roles and responsibilities of the stakeholders

\begin{tabular}{|c|c|}
\hline Stakeholder & Responsibility \\
\hline Project Sponsor & - Timely release of funds \\
\hline Supervisor & - Offer technical advice and guidance during project implementation \\
\hline Mentor & $\begin{array}{l}\text { - Offer mentorship, } \\
\text { - Support in accessing required information } \\
\text { - Availing facility staff involved in the project } \\
\text { - Overall decision maker on matters requiring further consensus } \\
\text { - Offer guidance for aligning the project with the needs of the hospital }\end{array}$ \\
\hline $\begin{array}{l}\text { Multidisciplinary team (project implementation team comprising of staff from } \\
\text { the hospital) }\end{array}$ & $\begin{array}{l}\text { - Identification of cost indicators } \\
\text { - Consolidating required information on a timely basis } \\
\text { - Participate in meetings } \\
\text { - Important in decision making \& assumptions building during tool } \\
\text { development } \\
\text { - Provide consensus during project implementation activities as } \\
\text { required }\end{array}$ \\
\hline Fellow & $\begin{array}{l}\text { - Carry out the project as the team lead } \\
\text { - Coordination of activities and stakeholders involved } \\
\text { - Draft working documents and prepare for discussion } \\
\text { - Moderate discussions during meetings } \\
\text { - Capture feedback, consolidate information provided and prepare } \\
\text { action points } \\
\text { - Train and offer technical expertise to multidisciplinary team } \\
\text { - Communicating project progress to all stakeholders/reporting } \\
\text { - Maintain confidentiality for all information provided. }\end{array}$ \\
\hline
\end{tabular}

\subsection{Communication strategies/plans/processes}

A communication strategy was crucial to the success of the project. It was necessary to clearly communicate and educate all involved in the project on the objectives of the project and what the project would achieve and how. General communications including invitations to meetings and sharing of information and reminders was done through emails where meeting summaries, status/progress reports, action points etc. were shared and phone calls were used where necessary. Monthly reports to UNITID were submitted through emails. All matters regarding the project implementation was communicated, shared and discussed by the project TWG and escalated to the CEO/mentor and supervisor as necessary through meetings and email communications.

The TWG held regular meetings to deliberate on activities and the implementation. Timely communication and follow ups were very important. The final outcomes of the project was shared in a dissemination forum for Mombasa County health department.

Table 2

Project communication Action plan

\subsection{Documentation}

All information gathered was documented and presented in notes to discussions, minutes of meetings as well as in monthly progress and feedback reports. Specific tools were developed for indicators collection e.g. indicators on costs and intervention outcomes. All information was documented and kept for reference. 
Assumptions were made where cost indicators were not be readily available. This required consensus meetings and all discussions taken into consideration before reaching a final decision. Adjustments of the cost indicators and discounting for assumptions were clearly stated.

\subsection{Risks and assumptions}

Accurate information availability on cost indicators at the facility remained the main assumption of the project. This was found to be true as though information was available, it was not present in the manner it could be utilized for costing.

\subsection{Sustainability plan}

The legal framework for economic evaluation of health interventions is currently embedded in the national health policy (MOH, Kenya Health Policy 20122030). This will be an important document where all health managers intending to carry out economic evaluations on health products, health technologies and health interventions will be anchored. It creates a support towards investing in economic evaluations by health facilities which is important for future sustainability.

Secondly, involving decision makers in the project helped ensure future sustainability in that it is relevant to their needs. The mentor at the hospital (CEO) and members of the technical/project multidisciplinary team directly participated in the project to ensure capacity was built in them for carrying out of similar tasks in future. Further to this, carrying out economic evaluations become embedded in the facilities health intervention programming through establishment of an economic evaluation team.

Lastly, at least two champions within the hospital were capacity built for hands on skills to carry out cost-effectiveness analysis to enhance future sustainability. A total of 22 members of staff comprising of departmental heads and managers were trained on the use of the tool and the team will continue to sustain the project in future.

\subsection{Project Implementation plan}

Table 3

Project implementation work plan

\begin{tabular}{|c|c|c|c|c|c|c|c|c|c|c|}
\hline Objective & Activities & Apr & May & June & July & Aug & Sept & Oct & Nov & Dec \\
\hline \multirow{12}{*}{$\begin{array}{l}\text { Obj. 1. Develop an excel } \\
\text { based cost effectiveness } \\
\text { analysis tool }\end{array}$} & Establish a working team at the facility & & & & & & & & & \\
\hline & $\begin{array}{l}\text { Sensitise and educate working team on objectives and } \\
\text { what the project will achieve }\end{array}$ & & & & & & & & & \\
\hline & $\begin{array}{l}\text { Develop terms of engagement for the team (Frequency } \\
\text { of meetings, agree on roles and responsibilities, discuss } \\
\text { communication processes) }\end{array}$ & & & & & & & & & \\
\hline & $\begin{array}{l}\text { Identification of programs where cost indicators will be } \\
\text { derived }\end{array}$ & & & & & & & & & \\
\hline & $\begin{array}{l}\text { Familiarize with operations generation of cost indicators } \\
\text { for identified programs }\end{array}$ & & & & & & & & & \\
\hline & Identify cost indicators & & & & & & & & & \\
\hline & Develop cost indicators collection tools & & & & & & & & & \\
\hline & Establish all cost indicators & & & & & & & & & \\
\hline & Validate information on cost indicators & & & & & & & & & \\
\hline & Develop and build consensus on cost indicators & & & & & & & & & \\
\hline & Design/draft excel tool & & & & & & & & & \\
\hline & Populate excel tool with cost indicators, formulas & & & & & & & & & \\
\hline $\begin{array}{l}\text { Obj. 2. Develop cost- } \\
\text { effectiveness manual }\end{array}$ & Develop working instructions for the excel tool & & & & & & & & & \\
\hline Obj. 3 Pre-test the tool & Perform sensitivity analysis & & & & & & & & & \\
\hline \multirow[t]{3}{*}{$\begin{array}{l}\text { Obj. } 4 \text { Train and } \\
\text { disseminate tool }\end{array}$} & $\begin{array}{l}\text { Establish a team to carry out economic evaluations in } \\
\text { the Hospital }\end{array}$ & & & & & & & & & \\
\hline & Train the team on use of the tool & & & & & & & & & \\
\hline & Disseminate tool to stakeholders & & & & & & & & & \\
\hline Reporting & Generating routing monthly/progress reports & & & & & & & & & \\
\hline
\end{tabular}

\subsection{Data sources}

The cost indicators (costs of various items) came from the accounts and finance department, and various user departments including existing program information. Additional information was gathered for assessment of the benefits against costs of HIV and other health interventions. For example; number HIV 
positive patients are on ART, of these how many adhered or were retained on treatment? How many transferred out?, How many were lost to follow up?, How many died?, Etc. These were a few areas that were utilized to build and develop a cost effectiveness analysis tool.

\subsection{Expected Outcomes and Deliverables}

Project Deliverables

Project deliverables included an excel-based tool and instructions manual for carrying out cost-effectiveness analysis at BOMU Hospital. The document will act as both a reference point as well as a working tool during cost-effectiveness analysis. Its regular review, improvements and utilization will be important for the hospital to fully benefit from the project and future activities. Further a training report and a dissemination report were generated.

Project Outcomes

The immediate outcome of the project included a general buy in and sensitization of the hospital staff towards use of economic evaluations for health interventions and its importance. All participants gained practical knowledge generated by and during the implementation of project. Capacity to carry out economic evaluations in the future was built into the staff including for two staff undertaking medium term courses who gained hands on experience. The capacitated staff henceforth became cost-effective conscious during laying out health interventions by making sure scarce health resources are employed optimally. Specifically, the project led to an increased understanding on the application of economic concepts and principals of economics in decision making for health. It also increased the understanding of the different methods of carrying out economic evaluations, handling uncertainties and making realistic assumptions during economic evaluation processes.

In addition, the staff not only showed competence but also confidence in planning for, carrying out and utilizing basic economic evaluation analysis during planning, budgeting, costing and implementation of health interventions at the hospital. Though the project was implemented at the hospital level, was necessary that the project outcomes and knowledge learnt be cascaded to other stakeholders in health. To support this, the project results and lessons learnt was shared with Mombasa County Health department stakeholders through a dissemination meeting.

Project Impact

The long term outcome will be availability of evidence based data to inform health care planning, budgeting, informed allocation of resources, costing and charging for services and an overall enhanced service delivery. This will contribute towards promoting equity and efficiency in the overall use of scarce health resources.

\subsection{Project Monitoring and Evaluation}

The progress of the project was monitored and evaluated for efficiency and alignment to the work plan. The work plan completion time for every activity remained a standing agenda in all meetings. Regular meetings and timely communication helped to maintain progress and to ensure activities were on course. Monthly reports were drawn and all reports submitted clearly indicated the progress of the project as per the work plan at all times. 
Table 4

Project implementation and evaluation plan:

\begin{tabular}{|c|c|c|c|c|c|c|c|c|}
\hline Objective & Activity & Indicator & $\begin{array}{l}\text { Outcome } \\
\text { /output }\end{array}$ & Baseline & Benchmark/Target & Data source & Frequency & Participants \\
\hline \multirow{12}{*}{$\begin{array}{l}\text { Ob. 1,2 \&3 1. To } \\
\text { develop a cost- } \\
\text { effectiveness } \\
\text { analysis excel tool } \\
\text { 2. To develop a } \\
\text { cost-effectiveness } \\
\text { analysis } \\
\text { manual/instructions } \\
\text { 3. To con-currently } \\
\text { pre-test the tool }\end{array}$} & $\begin{array}{l}\text { Establish a } \\
\text { multidisciplinary } \\
\text { working team at } \\
\text { the facility }\end{array}$ & $\begin{array}{l}\text { \# of staff } \\
\text { appointed; \#of } \\
\text { departmental } \\
\text { represented }\end{array}$ & Output & 0 & 8 & $\begin{array}{l}\text { Letters of } \\
\text { appointment }\end{array}$ & Once & Project MDT \\
\hline & $\begin{array}{l}\text { Sensitise and } \\
\text { educate working } \\
\text { team on } \\
\text { objectives and } \\
\text { what the project } \\
\text { will achieve }\end{array}$ & $\begin{array}{l}\text { \# of staff } \\
\text { sensitized; }\end{array}$ & Output & 0 & 8 & $\begin{array}{l}\text { Minutes, list } \\
\text { of } \\
\text { participants }\end{array}$ & \multirow[t]{3}{*}{ Once } & \multirow[t]{3}{*}{$\begin{array}{l}10 \text { members of } \\
\text { the project } \\
\text { MDT }\end{array}$} \\
\hline & $\begin{array}{l}\text { Develop terms } \\
\text { of engagement } \\
\text { for the team } \\
\text { (Frequency of } \\
\text { meetings, agree } \\
\text { on roles and } \\
\text { responsibilities, } \\
\text { discuss } \\
\text { communication } \\
\text { processes) }\end{array}$ & $\begin{array}{l}\text { Rules of } \\
\text { engagement, } \\
\text { Roles \& } \\
\text { responsibilities } \\
\text { and } \\
\text { communication } \\
\text { rules }\end{array}$ & Output & 0 & & $\begin{array}{l}\text { Minutes, } \\
\text { Participants } \\
\text { list }\end{array}$ & & \\
\hline & $\begin{array}{l}\text { Identification of } \\
\text { programs from } \\
\text { which cost } \\
\text { indicators will } \\
\text { be derived }\end{array}$ & $\begin{array}{l}\text { \# of programs } \\
\text { identified }\end{array}$ & Output & 0 & 2 & $\begin{array}{l}\text { Minutes, } \\
\text { Participants } \\
\text { list }\end{array}$ & & \\
\hline & $\begin{array}{l}\text { Familiarize with } \\
\text { operations in } \\
\text { generation of } \\
\text { cost indicators } \\
\text { for identified } \\
\text { programmes }\end{array}$ & & & 0 & $100 \%$ & $\begin{array}{l}\text { Cost } \\
\text { indicators } \\
\text { established }\end{array}$ & Once & $\begin{array}{l}\text { Fellow and All } \\
\text { members of } \\
\text { the project } \\
\text { team }\end{array}$ \\
\hline & $\begin{array}{l}\text { Identify cost } \\
\text { indicators }\end{array}$ & $\begin{array}{l}\text { List of cost } \\
\text { indicators }\end{array}$ & Output & 0 & 1 & $\begin{array}{l}\text { Minutes, } \\
\text { Participants } \\
\text { list }\end{array}$ & \multirow{7}{*}{$\begin{array}{l}16 \\
\text { meetings } \\
\text { held Bi- } \\
\text { monthly } \\
\text { (A Series } \\
\text { of MDT } \\
\text { meetings } \\
\text { held twice } \\
\text { a month } \\
\text { totaling to } \\
16 \\
\text { meetings } \\
\text { (May } \\
2016 \text { - } \\
\text { December } \\
2016 \text { ) }\end{array}$} & \multirow[t]{7}{*}{$\begin{array}{l}\text { Members of } \\
\text { the project } \\
\text { MDT }\end{array}$} \\
\hline & $\begin{array}{l}\text { Develop cost } \\
\text { indicators } \\
\text { collection tools }\end{array}$ & $\begin{array}{l}\text { Cost indicators } \\
\text { tool }\end{array}$ & Output & 0 & 1 & $\begin{array}{l}\text { Minutes, } \\
\text { Participants } \\
\text { list }\end{array}$ & & \\
\hline & $\begin{array}{l}\text { Establish and } \\
\text { consolidate a } \\
\text { list of all cost } \\
\text { indicators }\end{array}$ & $\begin{array}{l}\text { List of cost } \\
\text { indicators }\end{array}$ & Output & 0 & 1 & $\begin{array}{l}\text { Minutes, } \\
\text { Participants } \\
\text { list }\end{array}$ & & \\
\hline & $\begin{array}{l}\text { Validate } \\
\text { information on } \\
\text { cost indicators }\end{array}$ & $\begin{array}{l}\text { Validated list of } \\
\text { cost indicators }\end{array}$ & Output & 0 & 1 & $\begin{array}{l}\text { Minutes, } \\
\text { Participants } \\
\text { list }\end{array}$ & & \\
\hline & $\begin{array}{l}\text { Develop and } \\
\text { build consensus } \\
\text { on cost } \\
\text { indicators }\end{array}$ & $\begin{array}{l}\text { Final list of } \\
\text { cost indicators; } \\
\text { Assumptions }\end{array}$ & Output & 0 & 1 & $\begin{array}{l}\text { Minutes, } \\
\text { Participants } \\
\text { list }\end{array}$ & & \\
\hline & $\begin{array}{l}\text { Design/draft } \\
\text { excel too }\end{array}$ & Draft tool & Output & 0 & 1 & $\begin{array}{l}\text { Minutes, } \\
\text { Participants } \\
\text { list }\end{array}$ & & \\
\hline & $\begin{array}{l}\text { Populate excel } \\
\text { tool with cost } \\
\text { indicators, } \\
\text { formulas }\end{array}$ & Tool & Output & 0 & 1 & $\begin{array}{l}\text { Minutes, } \\
\text { Participants } \\
\text { list }\end{array}$ & & \\
\hline
\end{tabular}




\begin{tabular}{|c|c|c|c|c|c|c|c|c|}
\hline Objective & Activity & Indicator & $\begin{array}{l}\text { Outcome } \\
\text { /output }\end{array}$ & Baseline & Benchmark/Target & Data source & Frequency & Participants \\
\hline & $\begin{array}{l}\text { Develop working } \\
\text { instructions for } \\
\text { the excel tool } \\
\text { (To be done as } \\
\text { the tool is } \\
\text { populated) }\end{array}$ & $\begin{array}{l}\text { Tool with } \\
\text { working } \\
\text { instructions }\end{array}$ & Output & 0 & 1 & $\begin{array}{l}\text { Minutes, } \\
\text { Participants } \\
\text { list }\end{array}$ & & \\
\hline & $\begin{array}{l}\text { Perform } \\
\text { sensitivity } \\
\text { analysis }\end{array}$ & $\begin{array}{l}\text { Sensitivity } \\
\text { analysis report }\end{array}$ & Output & 0 & 1 & $\begin{array}{l}\text { Minutes, } \\
\text { Participants } \\
\text { list }\end{array}$ & & \\
\hline & $\begin{array}{l}\text { MDT Consensus } \\
\text { meetings }\end{array}$ & $\begin{array}{l}\text { \# of meetings } \\
\text { held }\end{array}$ & Output & 0 & 16 & $\begin{array}{l}\text { Minutes, } \\
\text { Participants } \\
\text { list }\end{array}$ & & \\
\hline & $\begin{array}{l}\text { Regular } \\
\text { presentation in } \\
\text { Hospital CMEs } \\
\text { (Once a month) }\end{array}$ & $\begin{array}{l}\text { \# of CMEs } \\
\text { presentation } \\
\text { done }\end{array}$ & Output & 0 & 8 & $\begin{array}{l}\text { Power point, } \\
\text { List of } \\
\text { participants }\end{array}$ & Monthly & All staff \\
\hline $\begin{array}{l}\text { Ob. } 4 \text {. To train staff } \\
\text { on the use of the } \\
\text { tool }\end{array}$ & $\begin{array}{l}\text { Train staff of } \\
\text { use of the tool }\end{array}$ & $\begin{array}{l}\text { \# of staff } \\
\text { trained }\end{array}$ & Output & 0 & 15 & $\begin{array}{l}\text { Lis of } \\
\text { participants, } \\
\text { Training } \\
\text { report }\end{array}$ & Once & $\begin{array}{l}25 \text { staff } \\
\text { including } \\
\text { departmental } \\
\text { heads }\end{array}$ \\
\hline $\begin{array}{l}\text { Obj. } 5 \text {. To } \\
\text { disseminate results }\end{array}$ & $\begin{array}{l}\text { Disseminate } \\
\text { tool to } \\
\text { stakeholders }\end{array}$ & $\begin{array}{l}\text { \# of } \\
\text { participants } \\
\text { disseminated } \\
\text { to }\end{array}$ & Output & 0 & 20 & $\begin{array}{l}\text { Participants } \\
\text { lists, } \\
\text { Dissemination } \\
\text { Report }\end{array}$ & Once & $\begin{array}{l}30 \text { (Include } \\
\text { County } \\
\text { representation) }\end{array}$ \\
\hline Others & $\begin{array}{l}\text { Generating } \\
\text { monthly } \\
\text { progress reports }\end{array}$ & $\begin{array}{l}\text { \# of reports } \\
\text { submitted }\end{array}$ & Output & & 8 & $\begin{array}{l}\text { Monthly } \\
\text { Reports }\end{array}$ & 8 & Fellow \\
\hline
\end{tabular}

\subsection{Ethical Issues}

The proposal was submitted to CDC for approval through the University of Nairobi Institute of Tropical and Infectious Diseases. Further, ethical concerns were handled carefully as they remain extremely important in gaining support from the project team. This included working within the values of the organization and focusing on the successes, interests and positive growth of the institution at all times. All due diligence was done to ensure engagement of the hospital management in decision making as a major stakeholder to ensure correctness of data and information utilized. Specifically, all data and information provided was held with utmost confidentiality and only summarized data and information was provided in progress reports. All information required was used only for the intended purpose of facilitating the implementation and completion of the project and for no other purpose.

\subsection{Results And Discussions}

\subsection{RESULTS}

The project was implemented through a participatory consultative approach with establishment of a technical working Group (TWG). The TWG comprised representation of nine (9) senior management staff from the hospital and the UON Fellow. Specific departments represented included procurement, human resource, HIV program, laboratory, pharmacy, in/out patient and finance. The TWG members participated in the whole process of development, training and dissemination of the tool while the mentor (Chief Executive Officer) helped to align the project to the needs of the hospital and offered overall guidance as per the defined roles and responsibilities.

An initial sensitization meeting was held with the appointed project TWG who were sensitized on the project, its objectives and deliverables. The TWG developed terms of engagement including frequency of meetings, clarifications on the roles and responsibilities, and the communication processes.

The second TWG meeting was also critical in identifying the programme from which information was to be used to develop the cost effectiveness analysis tool. The adult ART program was identified and an indicator collection tools were developed for collecting cost as well as program outcome indicators. 
The adult ART programme offers various services to HIV clients form the entry point of HIV testing and counseling, to enrollment into care, treatment, and treatment monitoring. Resource inputs (costs) and outputs (outcomes) information were therefore collected using an indicator collection tool to act as dummy data for use in developing the cost effectiveness analysis tool for the hospital.

Diagnosis services includes HIV testing and counselling, routine laboratory tests and baseline tests,

Treatment comprises of universal prophylaxis, enrollment into ART and clinical management of HIV as well as counselling on adherence to medication. Other aspects include sexual and reproductive health support services e.g. prevention and management of sexually transmitted illnesses (prevention with positives), provision of as well as education on correct and consistent use of condoms, treatment of opportunistic infections, nutrition services that include assessments, counselling, supplementation and nutrition treatment.

Treatment monitoring include laboratory testing, routine lab services to monitor clients receiving treatment and diagnosis of opportunistic Infections (Ols), viral load and CD4 monitoring, drug monitoring, drug resistance testing, drug toxicity monitoring, organ functions assessments etc. There are also other services that include medical records services (from initial client capture, identification and continual/long term client management including digitalization processes. Other services identified included hospital inpatient care (inpatients due to HIV), management of malignancies, blood transfusions, specialized consultant reviews, linkages and referral services (linkages from testing to treatment within facility departments and outside the facility, support services to care \& treatment clients (support groups, direct financial support from the hospital to HIV clients (e.g. transport, allowances to clients, Income Generating Activities (IGAs), youth friendly services, defaulter tracing, client education, communication, behaviors change messages, campaigns and materials including time allocated; palliative care and pain management; family care, psychosocial counselling, community based care as well as voluntary male medical circumcision. All services were comprehensively identified and service delivery points listed to facilitate comprehensive collection of all cost inputs and outcomes. Indicator collection templates were developed to collect the various type of information required.

Thereafter, a series of working meetings were held throughout the project implementation period. Meetings involved various activities all geared towards project implementation. This included learning, giving feedback on collected indicators, discussions on collected indicators, and reaching consensus on information collected as well as practicing on the draft sections of the tool as they were prepared. The TWG members gave feedback on the tool which helped in making improvements. Continuous learning was necessary to communicate health economics information to members of the TWG. This was done through power point presentations.

The output of the successful process include an excel tool with inbuilt instructions, a training report and a dissemination report. The TWG members appointment letter, indicator collection tools, minutes and participants lists to the series of meetings held are as presented in Appendixes.

3.2 Excel Based Cost Effectiveness Analysis Tool (Presented in form of a Compact Disc (CD).

The excel-based tool and inbuilt instructions remain the single most output of this project. The tool consists of several excel sheet sections which are described in details below:

\subsubsection{The Table of Content Section}

This is the section from which all other sections are accessed. Other sections are opened by simply clicking on the section name. Sections opened allow for moving back to the table of content page by clicking the BACK icon. The section of content page is protected from deletions or additions of any other information.

\subsubsection{The Cover Page}

The cover page contains the Bomu Logo, the author and affiliate institutions through which this tool was developed. The section allows for back and forward movement to other sections but it is protected from deletions or additions of any other information.

\subsubsection{The Introduction page}

This section briefly describes the background from which the tool was conceived and developed. This section also defines the responsible persons. The section allows for back and forward movement to other sections but it is protected from deletions or additions of any other information

\subsubsection{Intervention Outcomes Page}

The intervention outcomes page provides for identification of the intervention outcome(s) of interest before embarking on cost effectiveness analysis. The outcome to be used in the cost effectiveness analysis must be identified and determined in advance. The outcome must be similar for interventions being compared and must be ones that can be measured accurately. Where no two similar programs or intervention be identified, Cost Effectiveness Thresh holds are utilized. WHO defines an outcome as a "change in the health of an individual, group of people, or population that is attributable to an intervention or a series of interventions"

\subsubsection{Cost Elements Page.}

This section identifies and lists various departments within a hospital from which costing process can be applied. The departments are listed separately into to administrative and service delivery departments for easy of selection. It is important to assign costs to specific departments or units in the hospital so that we can then assign costs to cost objects. 
The section further identifies, categorizes and lists costs under four main categories for purposes of costing. The four main categories include Capital Costs, Overheads, Labor and Consumables/materials. This is the most important step in costing exercise and the purpose is to account for all costs incurred in full. Cost inputs and financial requirements for different interventions can vary widely in different facilities depending on the settings and the manner in which the services are designed and offered. Attempts have been made to further list several examples of cost elements under each cost category in detail for purpose of guiding the user. This section allows for additional cost elements to be added in each cost category so as to be as comprehensive as possible not to underestimate costs.

- Capital costs broken down to land, building, equipment.

- Equipment sub divided into general equipment and equipment specific to service delivery in both out and in patient settings

- Overheads

- Labour sub divided into administration and labour specific to service delivery

- Consumables which mainly include medicines, medical supplies and laboratory products are sub divided further into various classes for ease of relating to specific services and costing purposes e.g. HIV medicines, TB medicines, Malaria medicines, general medicines (tablets, injectable, oral liquids and external use medicines), nutrition supplements, vaccines, reproductive health products, laboratory reagents as well as non-pharmaceuticals.

The page allows for back and forward movement to other sections while being protected from deletions or any other manipulation other than addition of cost elements as may be required.

\subsubsection{Generating Units Costs Page}

The section allows for generation of unit costs through selection of various cost elements from a drop down list. This section draws information form the cost elements page linked through excel formulas.

- Drop down list allows ease of navigation and selection

- Allows quick search

- Acts as a guide

- Easy to add new elements on need

Generation of unit costs

Regardless of source of funds all costs that hospital expended or used for the day to day functioning in carrying out its operations were gathered. Two approaches were utilized in generating units costs; the top down approach and the bottom up approach.

Top-down approach

The top down approach was utilized in generating unit costs for indirect costs that could not be directly linked to the intervention. It involved summing up all annual expenditures per cost category and dividing by the number of clients served during the period giving average costs per client.

- Its less technical

- Less time consuming

- It is direct once total expenditure and total clients served are known

- Assumes all costs are the same

- Useful for calculating costs that may not be estimated in any other way

- Was utilized for capital costs, overheads and administrative labor costs

Bottom-up approach

The bottom up approach method was utilized for consumables especially medicines, medical supplies and laboratory reagents. It involves mapping and relating the expenditure to a certain treatment or test process for purposes of comprehensively identifying each individual item utilized. Usually, standard operating procedures and treatment or testing guidelines laid down are of great use here. An example is HIV testing where the process of testing include wearing of gloves, use of wipes for cleaning the skin, pricking for blood withdrawal, use of kit, wiping pricked area, use of buffer on withdrawn sample. The various items utilized are costed for and summed to constitute the cost per test.

- More technical and tedious

- Time consuming

- Gives more comprehensive and most accurate cost estimate

- Very useful for costing case specific costs for various treatments as it allows for direct individual client consumption costs such as medicines.

The method is important as it allows one to understand the process fully, can improve quality, impacts greatly on patient care

However, the method may not account for duplicate tests which is a great short coming. The challenge of consumables consumed in quality control e.g. proficiency testing are factored as a percentage. 
The costs associated with economic evaluation methods are derived from many different sources and include both direct and indirect costs, some of which are difficult to measure or estimate. The approach utilizing both the top down and bottom up costs measurement methods was considered more useful despite its short comings.

Discounting and depreciation of capital asset costs

Capital assets are those items acquired in one period but used not consumed all at once rather they are expended over several years. They include building, equipment, vehicles and land. Their full cost is thus spread over the useful life years while noting that they depreciate over time and also bearing in mind the present value of money. Useful life is the number of years a piece of asset can operate and is used to calculate the present value of future benefits which also helps accounts for inflation and aging. Present value (PV) annuity Factor is given by the formula

$$
\begin{aligned}
& \quad \text { Annuity PV Factor }=\frac{1-(1+r)^{-n}}{r} \\
& r=\text { rate per period } \\
& n=\text { number of periods }
\end{aligned}
$$

The interest rate $r$ is used to discount the annuity. The Present value annuity is then used to calculate. Annuity Due.

Annuity Due =

$$
\text { FV of Annuity Due }=(1+r) \times P\left[\frac{(1+r)^{n}-1}{r}\right]
$$

$$
\begin{aligned}
& P=\text { Periodic Payment } \\
& r=\text { rate per period } \\
& n=\text { number of periods }
\end{aligned}
$$

This formula relies on the concept of time value of money. Time value of money is the concept that a dollar received at a future date is worth less than if the same amount is received today. Though Annuity due tables are available, the formula was incorporated in the tool to avoid need to enter annuity values all times and only asset life years are required to be entered.

\section{2 .7}

Indirect costs Page

The section makes a summation of indirect costs per clients treated and allows viewing of the various indirect costs and their contribution to the total cost per client.

\subsubsection{Diagnosis Page}

The tool allows costing consumables for several independent tests from a bottom up approach. It also makes provision for costing laboratory equipment, personal time and laboratory consumables to get total costs of a test. The tool allows for diagnostic processes made by other personnel to be costed e.g. a medical personnel may use a spirometer to diagnose asthmatic cases or in the case of diagnosing a psychiatric patient by a specialist where no lab tests may be made.

\subsubsection{Treatment Page}

Costs for individual medicines are relatively easier to generate. Both program and non-program commodities have been costed. Provision was also been made to cost various disease conditions where more than one drug is used. This helps to give an average treatment cost per condition. Only medications and nonpharmaceuticals were considered under treatment.

\subsubsection{Treatment monitoring Page}

The section made provision for costing routine as well as targeted treatment monitoring. Both staff and equipment costs are accounted for. It also enables costing for both in and out-patient services. Hospitalization was assumed to be a monitoring process and was included in this section.

\subsubsection{Outcomes Page}

WHO defines an outcome as a "change in the health of an individual, group of people, or population that is attributable to an intervention or a series of interventions". The tool identifies three main possible outcomes namely:

- Cure or achievement of desired outcome 
- Treatment failure and

- Death

In addition, clients completing treatment/intervention, failing to complete treatment/intervention, defaulting and transferring out are accounted for in the effectiveness analysis. It will be necessary to carry out health outcomes research to clearly inform outcomes for interventions being compared.

\subsubsection{Cost Effectiveness Analysis Page}

Cost effectiveness analysis is the ratio of the cost of the intervention to a relevant measure of its effect. The tool calculated the measure of effect to cost for two interventions being assessed for effectiveness. In the absence of similar interventions that can be compared, Cost Effectiveness Thresholds may be employed. These are costs where policy makers have specified an explicit standard or thresh hold for what should be considered cost-effective and above which interventions are rejected on considered non-cost effective. WHO has based cost-effectiveness thresholds on a country's per-capita gross domestic product (GDP). The tool made provision for both

\subsubsection{Additional information pages}

Several excel sheets have been used to provide the user with more information about various terms used in the tool or sources of information. The user is able to access this information by clicking on instruction for "read more about". More sections utilized in consolidating calculations have also been hidden including key formulas:

3.3 Sensitivity analysis.

This is the process of characterizing uncertainty to enable decision makers make an informed decision. Examples of uncertainties

i. Uncertainty over treatment effects (outcomes); e.g. confidence intervals around estimates

ii. Methodological uncertainty e.g. rates of discounting used

iii. Uncertainty of data inputs e.g. costs and or

iv. Assumptions made

The inputs utilized in the cost effectiveness analysis and analyzed data is subjected to a sensitivity analysis to compensate for uncertainty. The process looks at "what if" to test the assumptions or estimates made within the process when precise input values could not be acquired. This is because values used and assumptions made are subject to change and error. Sensitivity analysis (SA), seeks to investigate these potential changes and errors and their impacts on conclusions. Basically, assumption values are varied in a sensitivity analysis and see how analyzed costs change while unresponsive parameters and scenarios are exclude from further analysis. The results are summarized for each key decision variable, while the values of a sensitivity index for all parameters and discrete scenarios are calculated and ranked by absolute value. This information was provided.

\subsection{Excel Based Cost Effectiveness Analysis Tool Instructions Manual}

The instructions were inbuilt within the tool. This was important to make reference easier during concurrent entry of data and interpretation of results. 3.5 Excel Based Cost Effectiveness Analysis Tool Training Report

Learning took place throughout the project implementation. Power point presentations were made during TWG working meetings for knowledge sharing. Additionally, a series of continuous medical education (CMEs) were prepared and incorporated into the institution CME schedule for purposes of sensitizing all staff. The learning process culminated in a two day training workshop where twenty three (23) Bomu Hospital staff were trained.

3.1.4 Excel Based Cost Effectiveness Analysis Tool Dissemination Report

A half day dissemination meeting was held in Mombasa County pooling membership from the County Health Department. Individual hospitals in Mombasa County were also represented.

\subsection{Discussion}

The project was a success and increased knowledge and skills among the staff on costing procedures and cost evaluation. The process will also impact on budgeting. Specifically,

- The implementation process fostered an environment for sustainability (involvement of CEO and TWG members)

- With regular use of the tool, implementation of cost effective interventions will enhance wide accessibility of HIV and other services to clients

- The tool will enhance cost savings. The hospital will be able to carry out own costing \& and cost evaluations rather than outsourcing for the same

- Excel based tool allows cost and intervention outcome data entry for healthcare workers with basic excel knowledge while outputs are automatically computed. Can be used by personnel with basic Information technology (IT), excel, research and data analysis backgrounds.

- Has features such as simple to use instructions, systematic listing of cost elements and a drop down option to allow selection as required.

- Allows additional cost elements to be added thus increasing scope of use

- The tool separates the various costs and sub-costs in a manner that allows cost drivers to be known precisely.

- The tool attempts to estimate different costs separately to the lowest detail possible. 
- It is acknowledged that results from accosting process may only be acceptable and implemented where the method used to derive costs is clear, convincing and practical. The tool makes this possible as each process is clear.

- The tool makes it possible for one to cost a certain cost and ignore another where it may not be necessary e.g., one may cost for personnel costs associated with a certain intervention while leaving the others costs out. Similarly, one may cost for consumables only, overheads only and vice versa. This takes into consideration that "true costs" of a service may be almost impossible to define because of complexities involved necessitating one to clearly indicate costs involved in every costing done (what is involved, what is excluded and all assumptions done).

- By listing various cost categories and sub categories, and use of drop down lists with pre-populated costs, this enables user to clearly categories costs and thus avoid double costing.eg consumables.

- Transferability: This tool can be in other health facilities

- Level of dissemination: The can be replicated in all hospitals within the country, in private, public and non - governmental organizations.

\section{Lessons learnt}

- Importance of stakeholder participation in the process

- Time management and effective communication is critical

- Opportunity to work in private sector setting

\section{Challenges}

- Information gap: Generally, concerns related to hospital level data have long been recognized as a major obstacle to any costing process. There was no prior collection of economic analysis data which had implication on the accuracy of results. In most areas assumptions were made and apportioning to departments as majority of cost information was consolidated together as hospital costs and not specific to departments.

- The current format in which information is kept at the hospital level was not optimal for analyzing and monitoring cost of services and or for costing purposes.

- Information was also not available to the level of detail needed for costing purposes requiring working backwards or making estimates for the required cost information. Administrative/financial information was more available and accurate than clinical records.

- Enabling the tool to cost and analyze effectiveness for varying interventions.

- Delayed approval and funding of project. This led to the need to extend the project time beyond the anticipated work plan.

- Availability of staff (staff work schedules). The project was implemented by a TWG comprising senior management staff who also performed their routine tasks.

\subsection{Conclusion And Recommendations}

In spite of data gap challenges, it was possible to utilize the available information collected to develop the excel-based tool. Making the tool as generic as possible remained the single most challenge all. This was overcame by creating what if scenarios and especially by making provision where information is not specific to a certain condition. The tool makes provision for case-based costing while being flexible enough for calculation of program costs. Its unique ability for transferability will help different facilities using the tool be able to compare their resource input in relation to outcomes and this forms a basis for comparing different health facilities performance, sharing best practices and offering possibility for standardization. Hospitals may use the tool to improve financial management.

The results of costing studies and cost effectiveness analysis will used as a basis for identifying areas of inefficiencies by comparing the costs and outputs with those of similar interventions or similar facilities etc. This is also useful in setting up or revising existing service charges for various interventions. It is however important to note that the analysis will be as accurate as the numbers entered. Health facilities attempting to use the tool must collect all costs and outcomes comprehensively and accurately.

It is highly recommended that economic evaluations be made a routine practice within the hospital. Institution are now in a position to participate in shaping decision making in financial allocations to health that could go a long way in informing health sector funding reforms. Facility may utilize the tool to inform outcome research studies. These are very useful in assessing clear health care services end points. Facilities need to embed economic evaluations in their strategic plans, health intervention programming and other working documents. This ensures that funds are formally allocated to the course. The tool's regular review, improvements and utilization will be important for facilities to fully benefit from the project.

\section{Declarations}

Ethical approvals and consent to participate: The proposal developed in collaboration with Bomu hospitals and Supervisor was submitted to CDC through the University of Nairobi Institute of Tropical and Infectious Diseases. Upon approval, the students were given go ahead to proceed with implementation.

Consent for publication: The Bomu CEO Dr. Aabid Ahmed whose hospital provided the information utilized in development of the Excel based Cost Effectiveness Analysis Tool provided consent for publication and he is a Co-Author.

Availability of data and materials: The Excel based Cost-Effectiveness Analysis Tool has been submitted alongside this manuscript. Data, including capital costs data such as equipment (medical and non-medical), overhead costs, labor, consumables and patients numbers and various outcomes utilized during this study are included in this published article as supplementary information files. 
Funding: The Centre for Disease Control met the full cost of study (school fees at the University of Nairobi and the project implementation costs upon approval of the proposal.)

Author's contributions:

Table 5

Authors and participants contributions

\begin{tabular}{|c|c|c|}
\hline Term & Definition & Contributor \\
\hline Conceptualization & Ideas; formulation or evolution of overarching research goals and aims & $\begin{array}{l}\text { Management Sciences for health, University of } \\
\text { Washington, Bomu Hospital, UON, UNITID- } \\
\text { (Organization Capacity assessment) }\end{array}$ \\
\hline \multirow{2}{*}{$\begin{array}{l}\text { Design of the } \\
\text { work }\end{array}$} & Proposal development & Dr. Nancy M. Njeru, \\
\hline & Proposal review and approval for submission to CDC & Dr. Elizabeth Owiti, Dr. Aabid Ahmed, \\
\hline Methodology & Development or design of methodology; creation of models & Dr. Nancy M Njeru \\
\hline $\begin{array}{l}\text { Software/Tool } \\
\text { design }\end{array}$ & $\begin{array}{l}\text { Programming, excel tool development; designing tool; implementation of the } \\
\text { tool outline and supporting algorithms; testing of formulas and functions }\end{array}$ & Dr. Nancy M. Njeru \\
\hline Validation & $\begin{array}{l}\text { Verification, whether as a part of the activity or separate, of the overall } \\
\text { replication/ reproducibility of results/experiments and other research outputs }\end{array}$ & Dr. Elizabeth Owiti, \\
\hline Formal analysis & $\begin{array}{l}\text { Application of statistical, mathematical, computational, or other formal } \\
\text { techniques to analyze or synthesize study data, development of assumptions }\end{array}$ & Dr. Nancy M. Njeru/ Bomu TWG participants \\
\hline $\begin{array}{l}\text { Interpretation of } \\
\text { data }\end{array}$ & Data interpretation, & Dr. Nancy M. Njeru \\
\hline Investigation & $\begin{array}{l}\text { Conducting a research and investigation process, specifically performing the } \\
\text { experiments, or data/evidence collection }\end{array}$ & Dr. Nancy M. Njeru, Bomu TWG \\
\hline Resources & $\begin{array}{l}\text { Provision of study materials, reagents, materials, patients, laboratory samples, } \\
\text { animals, instrumentation, computing resources, or other analysis tools }\end{array}$ & $\begin{array}{l}\text { Center for Disease Control (CDC); Funding full } \\
\text { cost of study } \\
\text { UON/UNITID-Lectures, Capacity building; Data } \\
\text { analysis software - Epi Info } \\
\text { Dr. Aabid Ahmed- Bomu hospital: Project site } \\
\text { hosting, office and infrastructure } \\
\text { - provided human resources(TWG members) and } \\
\text { hospital data }\end{array}$ \\
\hline Data Curation & $\begin{array}{l}\text { Management activities to annotate (produce metadata), scrub data and } \\
\text { maintain research data (including software code, where it is necessary for } \\
\text { interpreting the data itself) for initial use and later reuse }\end{array}$ & Dr. Nancy M. Njeru \\
\hline $\begin{array}{l}\text { Writing - Original } \\
\text { Draft }\end{array}$ & $\begin{array}{l}\text { Preparation, creation and/or presentation of the published work, specifically } \\
\text { writing the initial draft (including substantive translation) }\end{array}$ & Dr. Nancy M. Njeru \\
\hline $\begin{array}{l}\text { Writing - Review \& } \\
\text { Editing }\end{array}$ & $\begin{array}{l}\text { Preparation, creation and/or presentation of the published work by those from } \\
\text { the original research group, specifically critical review, commentary or revision - } \\
\text { including pre-or post-publication stages }\end{array}$ & $\begin{array}{l}\text { Dr. Nancy M Njeru, Dr. Elizabeth Owiti, Dr. Aabid } \\
\text { Ahmed }\end{array}$ \\
\hline Visualization & $\begin{array}{l}\text { Preparation, creation and/or presentation of the published work, specifically } \\
\text { visualization/ data presentation }\end{array}$ & Dr. Nancy M Njeru \\
\hline $\begin{array}{l}\text { Supervision and } \\
\text { mentorship }\end{array}$ & $\begin{array}{l}\text { Oversight and leadership responsibility for the research activity planning and } \\
\text { execution, including mentorship external to the core team }\end{array}$ & Elizabeth Owiti and Dr. Aabid Ahmed \\
\hline $\begin{array}{l}\text { Project } \\
\text { administration }\end{array}$ & $\begin{array}{l}\text { Management and coordination responsibility for the research activity planning } \\
\text { and execution }\end{array}$ & Dr. Nancy M Njeru \\
\hline $\begin{array}{l}\text { Funding } \\
\text { acquisition }\end{array}$ & Acquisition of the financial support for the project leading to this publication & UON/UNITID, CDC \\
\hline $\begin{array}{l}\text { Approval for } \\
\text { publication }\end{array}$ & $\begin{array}{l}\text { Approved the manuscripts for submission for publication and have agreed both } \\
\text { to be personally accountable for the work }\end{array}$ & Elizabeth Owiti and Dr. Aabid Ahmed \\
\hline
\end{tabular}

\section{Acknowledgements:}

I express my sincere gratitude you to the CEO, the management and the entire staff of Bomu Hospital and greatly appreciate the collaborative effort of all the individuals that actively devoted their time and skills to make this project a success. I also take this great opportunity to thank the University of Nairobi UHIV capacity building program for availing this great learning opportunity to me and more so the Centre for Disease Control (CDC) for providing financial support towards my studies and the implementation of the entire project.

Specifically, the following individuals who played a key role towards the overall success of the project are acknowledged for their immense contributions. 
- Elizabeth Owiti, UON

- Aabid Ahmed, Bomu Hospital

\section{TWG Members}

- Dr. Shaheed Ganiwalla - UNITID/BOMU contact person and Pharmacy I/C

- Nashina Mohamed - Head of programs

- Rumman Ahmed - Hospital Matron

- Rukiya Ali - Head, Finance

- Odilia Amalemba - Head, M\&E

- Mary Ondatto - Head, Human Resource

- Japheth Mdenyo - Laboratory Manager

- Neema Adam - Head, Procurement

- Eunice U. Mtsonga - UNITID Champion and Officer, Social programs

\section{References}

1. Andrew Creese \& David Parker 1994. Cost analysis in primary health care, A training manual for programme managers. WHO, Geneva.

2. Ann Mills and Kenneth Lee 1993; Health economics research in developing countries. Oxford University press, United States.

3. BOMU HOSPITAL ANNUAL OPERATIONAL PLAN 2016

4. Bomu Hospital Organizational Capacity assessment Report, April 2015

5. Bomu Medical Centre strategic Plan 2010-2015, A project of Mukomani Clinic society

6. James W. Henderson; Health Economics and Policy. $5^{\text {th }}$ Edition, International Edition: South Western Cengage Learning; 2012.

7. Lorna Guinness \& Virginia Wiseman. Introduction to health economics. $2^{\text {nd }}$ Open University press; 2011.

8. Ministry of health, National Health Accounts 2012-2013.

9. Ministry Of Health, Kenya Health Policy 2012-2030

10. Sophie Witter.; Tim Ensor.; Mathew Jowett.; and Robin Thompson. Health economics for developing countries. A practical guide. Macmillan, Malaysia; 2000.

11. WHO guide for standardization of economic evaluations of immunization programmes, 2014. Geneva

12. Ann Clin Biochem. A new approach to the costing of clinical laboratory tests P M G BROUGHTON AND T C HOGAN From the Wolfson Research Laboratories, Department of Clinical Chemistry, Queen Elizabeth Medical Centre, Birmingham B15 2TH; 1981.

13. Management Sciences for Health and World Health Organization. 2007. Drug and Therapeutics Committee Training Course. Trainers Guide

\section{Supplementary Files}

This is a list of supplementary files associated with this preprint. Click to download.

- LaboratoryReagentsConsumptionAdultARTBomuChangamwe.xIsx

- OverheadCostsHospitalProgramsOnly.xIsx

- HRRemunerationAdmin.xlsx

- Patientnumbersandtreatmentoutcomes.xlsx

- OverheadCostsHospitalProgramsOnly.xIsx

- LaboratoryReagentsConsumptionAdultARTBomuChangamwe.xlsx

- 20150lsandARVsConsumptionAdultARTChangamwe.xls

- 20130lsandARVsConsumptionAdultChangamwe.xls

- AdminOfficesequipmentandfurniture.xlsx

- 20140IsandARVsConsumptionAdultARTChangamwe.xls

- HRRemunerationAdmin.xlsx

- CapitalCosts.xlsx

- EquipmentinAdultARTProgramdepartment.xlsx

- AdminOfficesequipmentandfurniture.xlsx

- EquipmentinAdultARTProgramdepartment.xlsx

- CapitalCosts.xlsx

- HRRemunerationHealthWorkersAdultARTProgramOnly.xlsx

- HRRemunerationHealthWorkersAdultARTProgramOnly.xIsx 
Page 16/16 